\title{
RELATIONSHIPS OF FOREIGN EXCHANGE RATES WITH MACROECONOMIC VARIABLES, ECONOMIC CRISIS, AND TRADE VOLUMES: AN EMPIRICAL STUDY FROM INDIA
}

\author{
Dr. Kumar Bijoy ${ }^{1}$
}

DOI: https://doi.org/10.31410/ERAZ.2019.87

\begin{abstract}
Volatility in foreign exchange rates is an indicator of economic performance particularly for emerging market economies like India. This study tries to re-examine the relationship between exchange rates and macroeconomic variables for Indian economy. It addresses three issues, namely Volatility in exchange rates (USD/INR; EUR/INR and GBP/INR); Effect of Economic crisis represented by global financial crisis (GFC) and macroeconomic variables mainly Inflation and Yield of 10years Govt. Securities on above mentioned three exchange rates; and Relationship between exchange rates volatility and foreign trade (both export and import). Daily data for three exchange rates are taken for the period of January $3^{\text {rd }}$, 2000 to March $26^{\text {th }} 2019$, whereas for other two objectives, monthly average exchange rates are used along with monthly data for select macroeconomic variables for the period of Jan 2000 to Dec 2018. Volatility is represented by Standard Deviation and Causality is checked through Granger Causality Test. The findings suggest that volatility is highest for EUR/INR followed by GBP/INR and USD/INR. The average annual volatility for all three exchange rates indicates the minimum value in 2001 whereas maximum value for 2013. It is also observed that volatility is higher during crisis period compared to pre and post crisis periods for all three exchange rates. Granger Causality test suggests that out of 10 pairs of testing for causality only unidirectional cause effect relationships stating GBP granger causes yield on 10 years Government securities. The study further finds that USD/ INR exchange rate granger cause imports of India. These findings will help the market players at the time of taking their strategic decisions whereas to regulators during their policy decision process. For academicians and researchers, it provides an opportunity to explore the conditions with more macroeconomic variables and with the use of advanced econometric tools.
\end{abstract}

Keywords: Exchange rates, Global Financial crisis, Volatility, Granger Causality tests

\section{INTRODUCTION}

$\mathrm{U}$ nderstanding the relationship between the currency markets and macroeconomic variables is an essential component of international trade and investments as it involves exposure in foreign currencies. This relationship has received a considerable amount of attention from: economists, international investors and policymakers. Since the Opening of currency market in 1973, the linkage of exchange rate and macroeconomic variables became one of the important areas of study. Increasing integration of global financial markets (see Bekaert, Harvey, and Lumsdaine (1998); Otmar Issing (2000); Schumacher (2018)) has gradually increased the relevance of currency exchange rate fluctuation and it is expected to present some clear pattern of cause effect relationships both in short and long run with macroeconomic variables and economic happenings like financial crisis. Volatility in foreign exchange rates is an indicator of economic performance and its strength specially for emerging market economies like India. Higher volatility is perceived as higher risk in that economy (see Ilhan (2006)).

Department of Management studies, Shaheed Sukhdev College of Business Studies: University of Delhi, India 
Theoretically, in the long-term, a strong (appreciating) exchange rate tends to occur in countries with low inflation, improving competitiveness and a strong economic performance. A strong exchange rate is often considered to be a sign of economic strength. It may be perceived as a symbol of economic success and national pride. However, a contrary opinion is that a strong exchange rate can depress economic growth because exports become more expensive, leading to less demand for exports and more demand for imported goods as Imports become cheaper. Gradually it reduces aggregate demand (AD) for the domestically produced goods and push economy to downturn.

Economy trapped in downturn, evidenced by the rising Current account deficit (of Balance of Payments), may go for correction through policy interventions, especially devaluating the domestic currency. This will improve the current account position and will stimulate the economic growth as indicated in flow chart given below in figure 1.

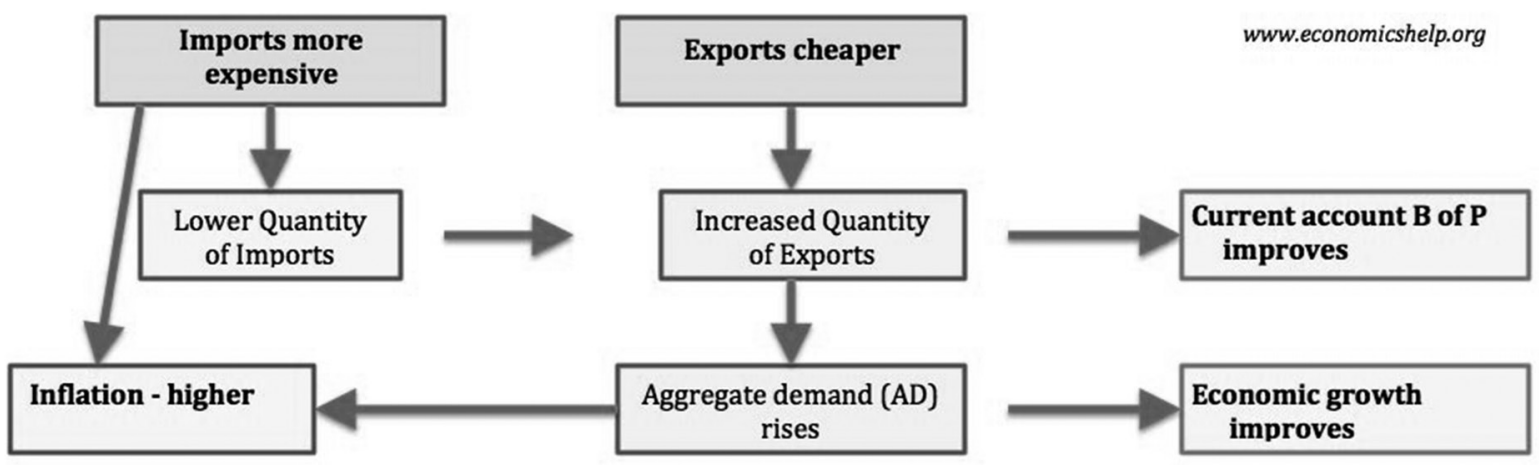

Figure 1. Flow chart showing effect of Devaluation on Current account of Balance of Payments and Economic Growth. (Source: economicshelp.org)

The study is organized as follows: Section two is review of literature whereas in section three we provide data and their sources. Methodology and estimation procedures are described in section four. In section five we provide empirical results while summary and policy suggestion are provided in the last section.

\section{REVIEW OF LITERATURE}

Review of previous studies indicates that the effort to find the relationships between Exchange rate volatility and different macroeconomic variables have been increasing in last one decade for emerging economies. Selim and Murat (2012) study the relationship between monthly Currency sale rates and Export series for Turkey at the turning points detected by Unit root test with one and two structural breaks. The findings reveal that exports are not influenced by structural turnings in the sale of currencies i.e. the export is not sensitive to the structural breaks and changes in currency rates. $\mathrm{Su}$ (2012) tries to find the long run equilibrium relationship between Renminbi (RMB) exchange rate and macroeconomic variables in China by using non-parametric rank tests (as proposed by Breitung) and the threshold error-correction model (TECM) to detect the nonlinear causal relationships. His findings support the nonlinear relationship with each other and asymmetrical error-correction process in China. Affandi and Mochtar (2013) in their study of current account and real exchange rate dynamics for Indonesian market observed the changing behavior of real exchange rate before and after year 2000. It is noticed that shift from temporary (before the year 2000) to permanent (after the year 2000) shocks is the cause of movement in real exchange rate. However, this behavioral shift doesn't affect the current 
account dynamics i.e. variance in current account after 2000 is also mainly due to temporary shocks. Dimitrios and Nicholas (2013) examine the effect of exchange rate volatility on sectoral exports for Croatia and Cyprus. Their findings suggest that exchange rate volatility has no effect on the level of exports for both the countries when measured through standard deviation of the log effective exchange but when measured through an alternative method then there is an indication of a stronger effect from movements of the exchange rate to the level of exports showing a negative statistical significant relationship for Croatia. Zubair et. al. (2014) in their study try to find the cause effect relationships between Exchange Rate, Imports, Exports, Foreign Reserves as independent variables and GDP of Pakistan as dependent variable. Their findings suggest that one basis point change in exchange rate can result in thousands of USD change in GDP. They further observed that depreciation of exchange rate has a positive impact on the exports, but sudden and abrupt fluctuation in exchange rates can disturb economic growth. Ramasamy and Abar (2015) in their study to find the influence of macroeconomic variables on three different exchange rates viz. AUD/USD, Euro/USD, AUD/Euro representing three countries USA, Australia and Germany. They selected nine macroeconomic variables namely interest rates, inflation rate, balance of payments, employment rate, corruption index, gross domestic product, deficit/surplus rate, tax rate and borrowing rate all relative values. They applied multi-model regression by linking complementary variables to identify the best model. Their findings suggest that all macroeconomic variables significantly influenced the exchange rates except employment and budget deficit. Salman et.al. (2015) find the long run relationship between the exchange rate and macroeconomic variables (GDP, inflation, interest rate and current account). They also find that exchange rate granger causes GDP and not the vice-versa for Pakistani economy. Sonaglio, Campos, and Braga (2016) attempt to examine the impact of changes in the monetary and exchange rate policies along with the composition of the total exports on the performance of the Brazilian economy. They use a structuralist model to evaluate the same. The findings reinforce the relevance of the manufacturing sector to economic growth, especially in a competitive exchange rate environment. Venkatesan and Ponnamma (2017) analyze the macroeconomic factors affecting Foreign Exchange in India by using ARDL model. It is found that FDI has a long-term relationship with the Indian rupee movements whereas in the short run this relationship is not straight forward, as it depends on specific characters of the economy. They also observed that Inflation had a negative impact on foreign exchange rate.

These studies are focused on some specific relationships or some specific geopolitical / economic zones or blocks. Their findings are also contrasting in nature. Some studies have concentrated on the relationships between the two variables with limited perspectives like effect of currency volatility on GDP of the economy. Further, very limited work is available for Indian economy. Thus, it has become necessary to study the relationship between Exchange Rates and macroeconomic variables along with trade volumes. These relationships should be studied to get a more comprehensive view about the information transmission processes. The present study is a step in this direction. Prime motivation of the proposed study is to re-examine the relationship between exchange rates and macroeconomic variables for Indian economy. The main objective of this study is to address three issues, namely: 1. Volatility in exchange rates (USD/INR; EUR/INR and GBP/INR), 2. Effect of Economic crisis represented by global financial crisis (GFC) and macroeconomic variables mainly Inflation and Yield of 10years Govt. Securities on above mentioned three exchange rates, 3. Relationship between exchange rates volatility and foreign trade (both export and import). 


\section{DATA}

To study the volatility, daily data for three exchange rates are taken for the period of January $3^{\text {rd }}, 2000$ to March $26^{\text {th }} 2019$, resulting to 5090 observations for each exchange rate whereas for other two objectives, monthly average exchange rates are used along with monthly data for the period of Jan 2000 to Dec 2018 for select macroeconomic variables totaling 228 observations. These variables are Inflation and Yield of 10years Govt. Securities. Monthly data for Imports and Exports are also taken for the same period. Data are collected from Reserve Bank of India (www.rbi.org.in).

\section{METHODOLOGY}

In this section, the methodologies employed for finding the relationships between forex rates and macroeconomic values are discussed. The volatility is also measured for all three exchange rates series through standard deviations on annual basis. This will indicate the nature and volatility trend for the select exchange rates. First of all, the stationarity test is done for these series by using Augmented Dickey-Fuller test (ADF). A time series $Y_{-} t(t=1,2 \ldots)$ is said to be stationary (in the weak sense) if its statistical properties do not vary with time (expectation, variance, autocorrelation). Identifying that a series is not stationary allows to afterwards study where the non-stationarity comes from. Unit root tests, such as the Dickey-Fuller test and its augmented version, the augmented Dickey-Fuller test (ADF), or the Phillips-Perron test (PP) may be applied to do the testing of stationarity. We applied ADF test to all the series i.e. Forex rates, Inflation, yield of 10years Govt. Securities; for all sample countries it is tested individually.

The second step is to determine the Lag length for Granger causality tests. Lag length is determined by using Vector Auto regression (VAR) Lag length selection criteria. The lag length which has the minimum value for Schwarz information criterion is used for causality test. We may use the Granger causality test in our study which is a statistical hypothesis test for determining whether one time series is useful in forecasting another.

A time series $X$ is said to Granger-cause $Y$ if it can be shown, usually through a series of t-test $\mathrm{s}$ and F-tests on lagged values of $X$ (and with lagged values of $Y$ also included); those $X$ values provide statistically significant information about future values of $Y$.

\section{EMPIRICAL FINDINGS}

All three exchange rates along with select macroeconomic variables are stationary at $1^{\text {st }}$ difference and their average volatility (measured through standard deviation) for the entire sample range is overall on higher side for all three with highest value for EUR/ INR (11.73) followed by GBP/INR (9.80) and USD/INR (9.38). The average annual volatility for all three exchange rates indicates the minimum value in 2001 (EUR/INR: 1.23; GBP/INR: 1.37) and in 2002 for USD/INR: 0.285 whereas maximum value for 2013 (EUR/INR: 6.13; GBP/INR: 7.65; USD/ INR: 3.90) (see Table1Panel A). As per Goldman Sachs this may be because of high inflation, high current account deficit, lower growth rate and FII outflow at domestic front and US Federal Reserve's decision to taper stimulus at external front. To find the impact of GFC on the exchange rate volatility, the whole sample gets divided into three periods namely pre-crisis (Jan 2000 to Aug 2007), crisis period (Sept 2007 to Jan 2009) and post crisis period (Feb 2009 to March 2019). It is interesting to observe that volatility is higher during crisis period compared 
to pre and post crisis periods for all three exchange rates (see Table1Panel B) agreeing with the previous findings (Kohler 2010). However, Post crisis period exhibits higher volatility compared to pre-crisis proving the continued but diminished effect of GFC on the exchange rates.

Granger Causality test suggests that out of 10 pairs of testing for causality only unidirectional cause effect relationships stating GBP granger causes yield on 10 years Government securities with the lag value 2 is significant at $5 \%$. Inflation has no causal relationships with any exchange rate or with 10-year G-Sec yield (see Table 2).

Theoretical understanding says that devaluation/depreciation of domestic currency makes import costly and unattractive whereas export attractive. However, this study doesn't find any such relationships between exchange rates and export/import of the country except in one case where USD/INR exchange rate granger cause imports of India (F statistics 5.03; p value: 0.0073) (See Table 3). The findings support the view of (Cristian and John 2011).

\section{SUMMARY AND CONCLUSION}

Volatility in foreign exchange rates is an indicator of economic performance for emerging market economies like India. Higher volatility is perceived as higher risk in that economy. This study tries to address three issues namely 1 . Volatility in exchange rates (USD/INR; EUR/INR and GBP/INR) 2. Effect of Economic crisis represented by global financial crisis (GFC) and macroeconomic variables mainly Inflation and Yield of 10years Govt. Securities on above mentioned three exchange rates, 3. Relationship between exchange rates volatility and foreign trade (both export and import). To study the volatility, daily data for three exchange rates are taken for the period of January $3^{\text {rd }}, 2000$ to March $26^{\text {th }} 2019$, whereas for other two objectives, monthly average exchange rates are used along with monthly data for the period of Jan 2000 to Dec 2018 for trade volume (import and export), inflation and yield on 10 year government securities. All three exchange rates along with select macroeconomic variables are stationary at $1^{\text {st }}$ difference and their average volatility (measured through standard deviation); for the entire sample range is overall on higher side for all three with highest value for EUR/ INR (11.73) followed by GBP/ INR (9.80) and USD/INR (9.38). To find the impact of GFC on the exchange rate volatility, the whole sample gets divided into three periods namely pre-crisis (Jan 2000 to Aug 2007), crisis period (Sept 2007 to Jan 2009) and post crisis period (Feb 2009 to March 2019). It is interesting to observe that volatility was higher during crisis period compared to pre and post crisis periods for all three exchange rates. However, Post crisis period exhibits higher volatility compared to pre-crisis proving the continued but diminished effect of GFC on the exchange rates. It is also observed that out of 10 pairs of testing for causality only unidirectional cause-effect relationships stating GBP granger causes yield on 10 years Government securities with the lag value 2 , is confirmed. Inflation has no causal relationships with any exchange rate or with 10-year G-Sec yield.

A convention that devaluation/depreciation of domestic currency makes import costly and unattractive whereas export attractive is not confirmed by this study except in one case where USD/ INR granger cause imports of India (F statistics 5.03; p val: 0.0073).

These findings will help the market players during their strategic decision makings whereas to regulators during their policy decision makings. For academicians and researchers, it provides an opportunity to explore the conditions with more macroeconomic variables and with the use of advanced econometric tools. 


\section{REFERENCES}

[1] Affandi, Yoga and Mochtar, Firman (2013) "Current Account and Real Exchange Rate Dynamics in Indonesia”, International Conference on Applied Economics (ICOAE) 2013, Procedia Economics and Finance 5, 20 - 29 Available online at www.sciencedirect.com

[2] Bekaert, Geert., Campbell R. Harvey., and Lumsdaine, Robin L. (1998) "Dating the Integration of World Equity Markets" NBER Working Paper No. 6724, NBER working paper Series

[3] Cristian, Broda., and John, Romalis. (2011), "Identifying the Relationship Between Trade and Exchange Rate Volatility", NBER Chapters, in: Commodity Prices and Markets, East Asia Seminar on Economics, Volume 20, pages 79-110 National Bureau of Economic Research, Inc.

[4] Dimitrios Serenis, and Nicholas Tsounis, (2013) "Exchange Rate Volatility and Foreign Trade: The case for Cyprus and Croatia", International Conference on Applied Economics (ICOAE) 2013, Procedia Economics and Finance 5, 677 - 685, Available online at www. sciencedirect.com

[5] Ilhan Ozturk (2006), "Exchange Rate Volatility and Trade: A Literature Survey", International Journal of Applied Econometrics and Quantitative Studies Vol.3-1

[6] Kohler, Marion. (2010) "Exchange rates during financial crises", BIS Quarterly Review, March 2010

[7] Otmar Issing (2000) "The globalisation of financial markets", European Central Bank Directorate General Communications Sonnemannstrasse 20, 60314 Frankfurt am Main, Germany

[8] Ramasamy, Ravindran. and Abar, Soroush Karimi. (2015) "Influence of Macroeconomic Variables on Exchange Rates", Journal of Economics, Business and Management, 3(2), p 276-281

[9] Salman, Aneel., Asghar, Nadia., Kahlon, Tahir U1 Mulk., Husnain, Iftikhar ul., and Makarevic, Nedim. (2015), "Liaison of Exchange Rate and Macroeconomic Variables: A Case Study of Pakistan” European Journal of Economic Studies, 2015, Vol. (14), Is. 4 pp. 221230

[10] Schumacher, Dieter. (2018) "The integration of international financial markets: an attempt to quantify contagion in an input-output-type analysis", Economic Systems Research DO I: $10.1080 / 09535314.2018 .1517084$

[11] Selim Demez., and Murat, Ustaoğlu. (2012) “Exchange-Rate Volatility's Impact on Turkey's Exports: An Empirical Analyze for 1992-2010”, International Conference on Leadership, Technology and Innovation Management, Procedia - Social and Behavioral Sciences 41, 168 - 176. Available online at www.sciencedirect.com

[12] Sonaglio, Cláudia Maria., Campos, Antonio Carvalho., and Braga, Marcelo José (2016) "Effects of interest and exchange rate policies on Brazilian exports", EconomiA 17 (2016) 77-95, Available online at www.sciencedirect.com

[13] Su, Chi-Wei. (2012) „The relationship between exchange rate and macroeconomic variables in China," Proceedings of Rijeka Faculty of Economics, University of Rijeka, Faculty of Economics, vol. 30(1), pages 33-56

[14] Zubair, Muhammad., Burney, Anwer Irshad., Sarwat, Salman., and Mubin, Muhammad. (2014) "Macroeconomics Relations between Exchange Rate Instability, Exchange Rate Volatility, Trade and Economic Growth Variables: The Case of Pakistan", Journal of Economics and Sustainable Development www.iiste.org ISSN 2222-1700 (Paper) ISSN 22222855 (Online) Vol.5, No.13. 
Table 1. Exchange Rate Volatility

Panel A. Average Annual Volatility (SD)

\begin{tabular}{|c|c|c|c|c|c|c|c|}
\hline Year & USD/INR & EUR/INR & GBP/INR & Year & USD/INR & EUR/INR & GBP/INR \\
\hline 2000 & 1.24147 & 1.463444 & 1.630487 & 2010 & 0.89625 & 3.012878 & 2.139643 \\
\hline 2001 & 0.55801 & 1.239639 & 1.370962 & 2011 & 2.69548 & 2.581804 & 3.313567 \\
\hline 2002 & 0.28504 & 2.477491 & 2.820777 & 2012 & 2.26502 & 2.073637 & 3.719252 \\
\hline 2003 & 0.90786 & 1.752078 & 1.987124 & 2013 & 3.90199 & 6.124834 & 7.645069 \\
\hline 2004 & 0.79596 & 1.791515 & 1.80478 & 2014 & 1.09996 & 2.870811 & 2.000302 \\
\hline 2005 & 0.8001 & 1.775084 & 2.166262 & 2015 & 1.62741 & 2.286129 & 3.125808 \\
\hline 2006 & 0.83033 & 2.332941 & 3.928679 & 2016 & 0.60879 & 1.377813 & 5.647086 \\
\hline 2007 & 1.79436 & 1.272124 & 2.409821 & 2017 & 1.23007 & 2.631906 & 1.823527 \\
\hline 2008 & 3.49055 & 3.075606 & 3.921078 & 2018 & 3.1504 & 2.052947 & 2.396656 \\
\hline 2009 & 1.42461 & 2.197668 & 3.193159 & $2019 *$ & 0.84523 & 1.154269 & 1.466646 \\
\hline
\end{tabular}

* only for three months (Jan -March 2019)

Panel B: Impact of GFC on the exchange rate volatility

\begin{tabular}{|l|r|r|r|}
\cline { 2 - 4 } \multicolumn{1}{c|}{} & USD/INR & EUR/INR & GBP/INR \\
\hline Pre-Crisis Period 2000 to Aug 2007 & 0.923 & 1.851 & 2.36 \\
\hline Crisis Period Sep 2007 to Jan 2009 & 2.601 & 2.803 & 2.886 \\
\hline Post-Crisis Period Feb 2009 to Mar 2019 & 2.123 & 3.025 & 3.875 \\
\hline
\end{tabular}

Table 2: Granger Causality test for 10 pairs (among Inflation, Euro, GBP, USD, yield on 10 years Government securities) at Lag 1 and 2

\begin{tabular}{|c|c|c|c|}
\hline Null Hypothesis: & Obs & F-Statistic & Prob. \\
\hline $\begin{array}{l}\text { INFLATION does not Granger Cause EUR } \\
\text { EUR does not Granger Cause INFLATION }\end{array}$ & 227 & $\begin{array}{l}1.97287 \\
0.82705\end{array}$ & $\begin{array}{l}0.1615 \\
0.3641\end{array}$ \\
\hline $\begin{array}{l}\text { GBP does not Granger Cause EUR } \\
\text { EUR does not Granger Cause GBP }\end{array}$ & 227 & $\begin{array}{l}1.20175 \\
2.12119 \\
\end{array}$ & $\begin{array}{l}0.2742 \\
0.1467 \\
\end{array}$ \\
\hline $\begin{array}{l}\text { USD does not Granger Cause EUR } \\
\text { EUR does not Granger Cause USD }\end{array}$ & 227 & $\begin{array}{l}0.19423 \\
1.07080\end{array}$ & $\begin{array}{l}0.6598 \\
0.3019\end{array}$ \\
\hline $\begin{array}{l}\text { YIELD does not Granger Cause EUR } \\
\text { EUR does not Granger Cause YIELD }\end{array}$ & 227 & $\begin{array}{l}2.08501 \\
1.62069 \\
\end{array}$ & $\begin{array}{l}0.1501 \\
0.2043 \\
\end{array}$ \\
\hline $\begin{array}{l}\text { GBP does not Granqer Cause INFLATION } \\
\text { INFLATION does not Granger Cause GBP }\end{array}$ & 227 & $\begin{array}{l}0.00886 \\
0.01944\end{array}$ & $\begin{array}{l}0.9251 \\
0.8892\end{array}$ \\
\hline $\begin{array}{l}\text { USD does not Granger Cause INFLATION } \\
\text { INFLATION does not Granger Cause USD }\end{array}$ & 227 & $\begin{array}{l}0.83816 \\
1.06853 \\
\end{array}$ & $\begin{array}{l}0.3609 \\
0.3024 \\
\end{array}$ \\
\hline $\begin{array}{l}\text { YIELD does not Granger Cause INFLATION } \\
\text { INFLATION does not Granger Cause YIELD }\end{array}$ & 227 & $\begin{array}{l}0.06348 \\
1.98605\end{array}$ & $\begin{array}{l}0.8013 \\
0.1601\end{array}$ \\
\hline $\begin{array}{l}\text { USD does not Granger Cause GBP } \\
\text { GBP does not Granger Cause USD }\end{array}$ & 227 & $\begin{array}{l}0.65620 \\
0.05962\end{array}$ & $\begin{array}{l}0.4188 \\
0.8073\end{array}$ \\
\hline $\begin{array}{l}\text { YIELD does not Granger Cause GBP } \\
\text { GBP does not Granger Cause YIELD }\end{array}$ & 227 & $\begin{array}{l}1.44010 \\
1.58132\end{array}$ & $\begin{array}{l}0.2314 \\
0.2099\end{array}$ \\
\hline $\begin{array}{l}\text { YIELD does not Granger Cause USD } \\
\text { USD does not Granger Cause YIELD }\end{array}$ & 227 & $\begin{array}{l}1.80375 \\
0.12808\end{array}$ & $\begin{array}{l}0.1806 \\
0.7208\end{array}$ \\
\hline
\end{tabular}

\begin{tabular}{|c|c|c|c|}
\hline Null Hypothesis: & Obs & F-Statistic & Prob. \\
\hline $\begin{array}{l}\text { INFLATION does not Granger Cause EUR } \\
\text { EUR does not Granger Cause INFLATION }\end{array}$ & 226 & $\begin{array}{l}1.22704 \\
0.42280\end{array}$ & $\begin{array}{l}0.2951 \\
0.6557\end{array}$ \\
\hline $\begin{array}{l}\text { GBP does not Granger Cause EUR } \\
\text { EUR does not Granger Cause GBP }\end{array}$ & 226 & $\begin{array}{l}0.79394 \\
2.15472\end{array}$ & $\begin{array}{l}0.4533 \\
0.1184\end{array}$ \\
\hline $\begin{array}{l}\text { USD does not Granger Cause EUR } \\
\text { EUR does not Granger Cause USD }\end{array}$ & 226 & $\begin{array}{l}0.15398 \\
0.65901\end{array}$ & $\begin{array}{l}0.8574 \\
0.5184\end{array}$ \\
\hline $\begin{array}{l}\text { YIELD does not Granger Cause EUR } \\
\text { EUR does not Granger Cause YIELD }\end{array}$ & 226 & $\begin{array}{l}1.12939 \\
1.45854\end{array}$ & $\begin{array}{l}0.3251 \\
0.2348\end{array}$ \\
\hline $\begin{array}{l}\text { GBP does not Grancer Cause INFLATION } \\
\text { INFLATION does not Granger Cause GBP }\end{array}$ & 226 & $\begin{array}{l}1.01507 \\
0.38134\end{array}$ & $\begin{array}{l}0.3641 \\
0.6834\end{array}$ \\
\hline $\begin{array}{l}\text { USD does not Granger Cause INFLATION } \\
\text { INFLATION does not Granger Cause USD }\end{array}$ & 226 & $\begin{array}{l}0.70889 \\
0.38219\end{array}$ & $\begin{array}{l}0.4933 \\
0.6828\end{array}$ \\
\hline $\begin{array}{l}\text { YIELD does not Granger Cause INFLATION } \\
\text { INFLATION does not Granger Cause YIELLD }\end{array}$ & 226 & $\begin{array}{l}0.64932 \\
1.22302\end{array}$ & $\begin{array}{l}0.5234 \\
0.2963\end{array}$ \\
\hline $\begin{array}{l}\text { USD does not Granger Cause GBP } \\
\text { GBP does not Granger Cause USD }\end{array}$ & 226 & $\begin{array}{l}0.36369 \\
0.03774\end{array}$ & $\begin{array}{l}0.6955 \\
0.9630\end{array}$ \\
\hline $\begin{array}{l}\text { YIELD does not Granger Cause GBP } \\
\text { GBP does not Granger Cause YIELD }\end{array}$ & 226 & $\begin{array}{l}0.69839 \\
9.95673\end{array}$ & $\begin{array}{l}0.4985 \\
7 . E-05\end{array}$ \\
\hline $\begin{array}{l}\text { YIELD does not Granger Cause USD } \\
\text { USD does not Granger Cause YIELD }\end{array}$ & 226 & $\begin{array}{l}1.38886 \\
1.07282\end{array}$ & $\begin{array}{l}0.2515 \\
0.3438\end{array}$ \\
\hline
\end{tabular}


Table 3. Granger Causality Test between Imports \& Exports of India and select Exchange rates

USD/INR Exchange rate Vs Imports and Exports of India

Sample: 2000M01 2018M12

Lags: 2

\begin{tabular}{lccc}
\hline \hline Null Hypothesis: & Obs & F-Statistic & Prob. \\
\hline \hline D(IMPORTS) does not Granger Cause D(EXCHANGERATE) & 225 & 0.42323 & 0.6555 \\
D(EXCHANGERATE) does not Granger Cause D(IMPORTS) & & 5.03107 & 0.0073 \\
\hline \hline D(EXPORTS) does not Granger Cause D(EXCHANGERATE) & 225 & 0.59761 & 0.5510 \\
D(EXCHANGERATE) does not Granger Cause D(EXPORTS) & & 1.70711 & 0.1838 \\
\hline \hline
\end{tabular}

EUR/INR Exchange rate Vs Import and Export of India

Sample: 2000M01 2018M12

Lags: 2

\begin{tabular}{lccc}
\hline \hline Null Hypothesis: & Obs & F-Statistic & Prob. \\
\hline \hline D(EXPORTS) does not Granger Cause D(EXCHANGERATE) & 225 & 0.07316 & 0.9295 \\
D(EXCHANGERATE) does not Granger Cause D(EXPORTS) & & 1.89200 & 0.1532 \\
\hline \hline D(IMPORTS) does not Granger Cause D(EXCHANGERATE) & 225 & 0.17068 & 0.8432 \\
D(EXCHANGERATE) does not Granger Cause D(IMPORTS) & & 0.90317 & 0.4068 \\
\hline
\end{tabular}

GBP/INR Exchange rate Vs Import and Export of India

Sample: 2000M01 2018M12

Lags: 2

\begin{tabular}{lccc}
\hline \hline Null Hypothesis: & Obs & F-Statistic & Prob. \\
\hline \hline D(IMPORTS) does not Granger Cause D(EXCHANGERATE) & 224 & 1.09969 & 0.3348 \\
D(EXCHANGERATE) does not Granger Cause D(IMPORTS) & & 1.37110 & 0.2560 \\
\hline \hline D(EXPORTS) does not Granger Cause D(EXCHANGERATE) & 225 & 0.52062 & 0.5949 \\
D(EXCHANGERATE) does not Granger Cause D(EXPORTS) & & 0.49487 & 0.6103 \\
\hline \hline
\end{tabular}

